\title{
PENGARUH MODEL PEMBELAJARAN GROUP INVESTIGATION BERBASIS BUDAYA PENYELIDIKAN TERHADAP KOMPETENSI PENGETAHUAN IPA KELAS IV
}

\author{
${ }^{1}$ Dewa Ayu Rai Yuniari, ${ }^{2}$ Made Putra, ${ }^{3}$ I Wayan Wiarta \\ ${ }^{1}$ Jurusan Pendidikan Dasar Universitas Pendidikan Ganesha \\ e-mail:dewa.ayu.rai.yuniari@undiksha.ac.id ${ }^{1}$,madeputra@undiksha.ac..id', \\ iwayan.wiarta@undiksha.ac.id
}

\begin{abstract}
Abstrak
Penelitian ini bertujuan untuk mengetahui pengaruh model pembelajaran Group Investigation berbasis budaya penyelidikan terhadap kompetensi pengetahuan IPA kelas IV SDN Gugus Kapten Kompyang Sujana. Desain penelitian ini adalah Penelitian Eksperimen semu dengan rancangan Non-Equivalent Post Test Only Control Group Design. Populasi penelitian ini seluruh kelas IV SDN Gugus Kapten Kompyang Sujana sebanyak 562 Siswa. Sampel diambil dengan teknik Random Sampling. Sampel dalam penelitian ini yaitu SDN 9 Padangsambian sebagai kelas eksperimen sebanyak 40 siswa dan SDN 2 Padangsambian sebagai kelas kontrol sebanyak 39 siswa. Data hasil kompetensi pengetahuan IPA dikumpulkan dengan menggunakan tes objektif tipe pilihan ganda biasa. Data yang diperoleh dianalisis menggunakan uji-t. Hasil analisis data diperoleh $t_{\text {hitung }}=5,694$ sedangkan pada taraf signifikansi $5 \%$ dan $d k=77$ diperoleh nilai $t_{\text {tabel }}=2,000$ sehingga $t_{\text {hitung }}$ $=5,694>t_{\text {tabel }}=2,000$. Berdasarkan kriterian pengujian, maka Ho ditolak. Hasil Penelitian menunjukkan nilai rata-rata kelompok eksperimen lebih dari pada kelompok kontrol ( $\bar{X}=$ $82,80>\bar{X}=73,28$ ). Jadi dapat disimpulkan bahwa terdapat pengaruh model pembelajaran Group Investigation berbasis budaya penyelidikan terhadap kompetensi pengetahuan IPA siswa kelas IV SDN Gugus Kapten Kompyang Sujana.
\end{abstract}

Kata-kata kunci: group investigation, budaya penyelidikan, IPA

\begin{abstract}
This study aims to determine the effect of culture-based Group Investigation learning models of inquiry on fourth grade science knowledge competencies SDN Gugus Kapyang Kompyang Sujana. The design of this study was a quasi-experimental study with a design of Non-Equivalent Post Test Only Control Group Design. The population of this study were all class IV SDN Gugus Kapyang Kompyang Sujana as many as 562 students. The sample is taken by Random Sampling. The sample in this study were SDN 9 Padangsambian as an experimental class as many as 40 students and SDN 2 Padangsambian as a control class as many as 39 students. Data on science competency knowledge results were collected using the usual multiple choice type objective test. The data obtained were analyzed using the $t$-test. The results of data analysis obtained $t_{\text {count }}=5.694$ while at the significance level of $5 \%$ and $\mathrm{dk}=77$ obtained $t_{\text {table }}=2.000$ so that $t_{\text {count }}=5.694>t_{\text {table }}=2.00$. Based on the testing criteria, Ho is rejected. The results showed that the average value of the experimental group was more than the control group $(=82.80>=73.28)$. So it can be concluded that there is an
\end{abstract}


influence of the culture-based Group Investigation learning model of inquiry on science knowledge competencies of fourth grade students at SDN Gugus Kapyang Kompyang Sujana.

Keywords : Gl, culture of inquiry, science

\section{PENDAHULUAN}

Undang-Undang Sistem Pendidikan Nasional Nomor 20 Tahun 2003 mengamanatkan konsep pendidikan yang harus dituju oleh bangsa Indonesia. Pendidikan Nasional berfungsi untuk mengembangkan kemampuan dan membentuk watak serta peradaban bangsa yang bermartabat dalam rangka mencerdaskan kehidupan bangsa. Pendidikan memberikan kemungkinan pada peserta didik untuk memperoleh "kesempatan", "harapan", dan "pengetahuan" agar dapat hidup secara lebih baik. Pendidikan yang berkualitas tentunya melibatkan peserta didik untuk aktif belajar dan mengarahkan terbentuknya nilai-nilai yang dibutuhkan oleh peseta didik dalam menempuh kehidupan.

Dalam mencapai tujuan pendidikan nasional tentunya penyelenggaraan pembelajaran di sekolah harus berjalan dengan baik. Salah satunya adalah dengan melakukan berbagai upaya agar perkembangan dunia pendidikan semakin maju seperti peningkatan kompetensi guru, peningkatan sarana dan prasarana serta pengembangan kurikulum. Kurikulum 2013 merupakan kurikulum yang berlaku untuk saat ini, kurikulum ini memiliki tujuan untuk mengembangkan potensi peserta didik baik sikap religious, sikap sosial, intelektual, kemampuan berkomunikasi, sikap peduli, dan partisipasi aktif dalam membangun kehidupan berbangsa dan bermasyarakat yang lebih baik.

Proses pembelajaran yang dilakukan di sekolah tidak terlepas dari komponenkomponen pembelajaran yang mencakup : tujuan, materi ajar, pendekatan dan metode, media, sumber belajar dan evaluasi pembelajaran. Proses pembelajaran yang berlangsung membutuhkan kerjasama dari segala aspek dan komponen pembelajaran agar tercapainya tujuan pembelajaran. Dari sekian banyak komponen yang berpengaruh, komponen guru merupakan salah satu komponen yang menentukan, sebab guru merupakan ujung tombak yang secara langsung berhubungan dengan siswa sebagai objek dan subjek belajar.

Pada jenjang pendidikan sekolah dasar, dalam pembelajaran tematik siswa dibelajarkan sejumlah mata pelajaran salah satunya adalah IImu Pengetahuan Alam (IPA). Samatowa (2016:3) menyatakan "IPA membahas tentang gejala-gejala alam yang disusun secara sistematis yang didasarkan pada hasil percobaan dan pengamatan yang dilakukan oleh manusia". Pembelajaran IPA di SD sangat penting bagi siswa. Dengan memberikan pembelajaran IPA di SD, maka siswa dapat menguasai pengetahuan fakta, konsep, prinsip, proses penemuan, serta memiliki sikap ilmiah, yang akan bermanfaat bagi siswa dalam mempelajari diri dan alam sekitar.

Berdasarkan hasil observasi dan wawancara dengan ketua gugus, kepala sekolah dan guru kelas IV SDN Gugus Kapten Kompyang Sujana, memperlihatkan bahwa dalam proses pembelajaran berkaitan dengan muatan materi IPA masih monoton. Kecenderungan untuk menggunakan model pembelajaran konvensional masih melekat pada setiap pembelajaran terutama mata pelajaran IPA. Sehingga tujuan pembelajaran tidak tercapai dengan maksimal. Dalam proses pembelajaran siswa cenderung merasa bosan dikarenakan kurangnya inovasi dalam penggunaan model pembelajaran.

Berkaitan dengan hal tersebut, inovasi dalam proses pembelajaran sangat diperlukan. Salah satu inovasi dalam proses pembelajaran yang dapat dilakukan adalah dengan 
menggunakan model pembelajaran yang lebih melibatkan siswa dalam proses pembelajaran serta pemecahan masalah yang dihadapi dalam pembelajaran, sehingga siswa selalu aktif dalam proses pembelajaran. Pada saat ini telah berkembang berbagai model pembelajaran yang inovatif untuk menunjang proses pembelajaran IPA di SD. Salah satu model tersebut yaitu Model Group Investigation.

Kurniasih dan Sani (2016:71) menyatakan "model pembelajaran Group Investigation adalah salah satu bentuk model pembelajaran kooperatif yang menekankan pada partisipasi dan aktivitas siswa untuk mencari sendiri materi atau segala sesuatu mengenai materi pelajaran yang akan dipelajari." Pembelajaran dengan menggunakan model Group Investiation sangat cocok di terapkan dalam pembelajaran IPA, dikarenakan dalam model ini siswa dituntut untuk dapat berperan aktif serta melakukan kegiatan investigasi dalam pembelajaran. Model Pembelajaran Group Investigation merupakan salah satu tipe dari model pembelajaran kooperatif. Pembelajaran kooperatif adalah suatu metode belajar dimana siswa belajar dalam kelompok-kelompok kecil yang beranggotakan 4-6 orang siswa yang memiliki tingkat kemampuan yang berbeda, kelompok kecil ini setiap anggotanya dituntut untuk saling bekerjasama antar anggota kelompok yang satu dengan yang lain.

Menurut Shoimin (2014:80) model pembelajaran Group Investigation adalah "suatu model pembelajaran yang lebih menekankan pada pilihan dan kotrol siswa daripada menetapkan teknik-teknik pengajaran di ruang kelas." Selain itu, Narudin (dalam Shoimin, 2014:80) mengatakan bahwa Group Investigation merupakan salah satu bentuk model pembelajaran kooperatif yang menekankan pada partisipasi dan aktifitas siswa untuk mencari sendiri materi (informasi) pelajaran yang akan dipelajari melalui bahan-bahan yang tersedia, misalnya dari buku pelajaran atau internet.

Model ini harus melibatkan siswa mulai dari perencanaan, baik dalam menentukan topik maupun cara untuk mempelajarinya melalui investigasi. Tipe ini menuntut para siswa untuk memiliki kemampuan yang baik dalam berkomunikasi maupun dalam keterampilan proses kelompok. Hal yang paling penting dari model ini adalah dapat melatih siswa untuk menumbuhkan kemampuan berfikir mandiri (Kurniasih dan Sani, 2016:71).

Dalam teori yang ada, model pembelajaran Group Investigation ini ada tiga konsep utama, yaitu: penelitian, pengetahuan, dan dinamika kelompok. Penelitian disini adalah proses dinamika siswa memberikan respon terhadap masalah dan memecahkan masalah tersebut. Pengetahuan adalah pengalaman belajar yang diperoleh siswa baik secara langsung maupun tidak langsung. Sedangkan dinamika kelompok menujukan suasana yang menggambarkan sekelompok saling berinteraksi yang melibatkan berbagai ide dan pendapat serta saling bertukar pengalaman melaui proses saling berargumentasi.

Diantara model-model belajar yang tercipta, Group Investigation merupakan salah satu model pembelajaran yang bersifat demokratis karena siswa menjadi aktif belajar dan melatih kemandirian dalam belajar. Sohimin (2014:81-82) mengungkapkan model pembelajaran Group Investigation memiliki beberapa kelebihan, yaitu: (1)Secara Pribadi, (a)Dalam proses belajarnya dapat bekerja secara bebas. (b)Memberi semangat untuk berinisiatif, kreatif, dan aktif. (c)Rasa percaya diri akan lebih meningkat. (d)Dapat belajar untuk memecahkan dan menangani suatu masalah. (e)Mengembangkan antusiasme dan rasa pada fisik. (2)Secara Social, (a)Meningkatkan belajar bekerja sama. (b)Belajar berkomunikasi baik dengan teman sendiri maupun guru. (c)Belajar berkomunikasi yang baik secara sistematis. (d)Belajar menghargai pendapat orang lain. 
(e)Meningkatkan partisipasi dalam membuat suatu keputusan. (3)Secara Akademis, (a)Siswa terlatih untuk mempertanggungjawabkan jawaban yang diberikan. (b)Bekerja secara sistematis. (c)Mengembangkan dan melatih keterampilan fisik dalam berbagai bidang. (d) Merencanakan dan mengorganisasikan pekerjaannya. (e) Mengecek kebenaran jawaban yang mereka buat. (f) Selalu berpikir tentang cara atau strategi yang digunakan sehingga didapat suatu kesimpulan yang berlaku umum. Sebelum memulai pembelajaran, guru dan siswa harus mengetahui langkah-langkah pembelajaran Group Investigation. Menurut Kurniasih dan Sani (2016:74-75) proses pembelajaran Group Investigation terdiri dari beberapa langkah yaitu :(a)Menyeleksi topik, (b)Merencanakan kerjasama, (c) Pelaksanaan, (d) Analisis sintesis, (e) Penyajian hasil akhir, (f) Melakukan evaluasi. Pengoptimalan kompetensi pengetahuan siswa melalui penerapan model Group Investigation masih memerlukan kegiatan perangsang, salah satunya dengan pembelajaran yang berbasis budaya penyelidikan, National Science Teacher's Association (2013:48) penyelidikan dapat memberi kesempatan untuk melibatkan siswa pada penelitian ilmiah, mempertajam kemampuan berpikir kritis, dan meningkatkan kesadaran akan pentingnya riset mendasar. Budaya penyelidikan adalah pola sikap yang menjadi cara atau pedoman yang digunakan untuk menggali, menjelaskan dan mengenal sesuatu (Nalasari,2016). Penyelidikan mengacu pada proses intelektual yang telah dilakukan oleh manusia selama ribuan tahun. National Science Education Standards (dalam National Science Teacher's Association 2013:46) menyebutkan bahwa:

Penyelidikan ilmiah mengacu pada berbagai macam cara yang dipakai ilmuwan, untuk mempelajari alam dan mengungkapkan penjelasan berdasarkan bukti yang mereka peroleh dari proses itu. Penyelidikan juga mengacu pada aktivitas yang dilakukan siswa untuk mengembangkan pengetahuan dan pemahaman mengaai gagasan-gagasan ilmiah,serta pemahaman mengenai bagaimana ilmuwan memelajari alam.

Pembelajaran dengan berbasis pada budaya penyelidikan dapat memberi kesempatan untuk melibatkan siswa pada penelitian ilmiah, mempertajam kemampuan berpikir kritis, dan meningkatkan kesadaran akan pentingnya riset mendasar (National Science Teacher's Association, 2013). Proses untuk memperoleh pemahaman dan kemampuan melakukan penyelidikan, akan selalu dijalani oleh siswa saat bersekolah. Siswa yang terlibat dalam penyelidikan mengembangkan: (1)Pemahaman mengenai konsep ilmiah, (2)Kesadaran mengenai bagaimana kita mengetahui apa yang kita ketahui dalam sains, (3)Pemahaman terhadap sifat sains, (4)Kemampuan yang diperlukan untuk menjadi penyelidik mandiri mengenai dunia, dan (5)Kecendrungan untuk memakai pemahaman dan kemampuan dalam sains saat menganalisis informasi baru.

Terdapat beberapa ciri pokok penyelidikan menurut National Science Teacher's Association (2013:52) yaitu : (1)Siswa terlibat dalam pertanyaan yang berorientasi pada sains. (2)Siswa memprioritaskan bukti saat menjawab pertanyaan. (3)Siswa merumuskan penjelasan dari bukti. (4)Siswa menghubungkan penjelasan dengan pengetahuan ilmiah. (5)Siswa menyampaikan dan membenarkan penjelasan.

Berkaitan dengan hal tersebut, model pembelajaran Group Investigation dapat dikembangkan dan dipadukan dengan budaya penyelidikan. Sehingga dapat disimpulkan, model pembelajaran Group Investigation berbasis budaya penyelidikan merupakan kegiatan pembelajaran yang mendorong siswa untuk mampu memahami, menemukan dan merekonstruksi konsep yang sedang dipelajari dan didasarkan pada pengembangan cara menyelidiki agar pembelajaran menjadi bermakna. 


\section{METODE}

Penelitian ini dilaksanakan di SD Negeri Gugus Kapten Kompyang Sujana. Adapun jenis penelitian yang dilakukan dalam penelitian ini adalah penelitian kuantitatif dengan desain eksperimental yaitu quasi eksperiment (eksperimen semu). Yang membedakan antara true eksperimen dengan quasi eksperiment adalah adanya random assignment pada true eksperiment, ketiga desain pada kelompok true eksperimen akan berubah menjadi quasi eksperiment manakala peneliti tidak melakukan random assignment, tetapi menggunakan kelompok atau kelas-kelas yang sedang berlangsung sebagai kelompok eksperiment dan kelompok kontrol (Salimah, 2011:192). Desain yang digunakan adalah "non-equivalent post test only control group design". Dalam desain ini terdapat dua kelompok, yaitu kelompok eksperimen dan kelompok kontrol. Desain penelitian ini dapat dilihat pada gambar di bawah ini :

\begin{tabular}{ccc}
\hline Kelas & Perlakuan & Post-test \\
\hline Eksperimen & $\mathrm{X}_{1}$ & $\mathrm{O}_{1}$ \\
\hline Kontrol & $\mathrm{X}_{2}$ & $\mathrm{O}_{2}$ \\
\hline \multicolumn{4}{c}{ Gambar 1. } \\
"Non-Equivalent Post Test Only Control Group Design"
\end{tabular}

Keterangan :

(Sumber: Agung,2014:163)

$\mathrm{X}_{1} \quad=$ Perlakuan pada kelompok eksperimen

$\mathrm{X}_{2} \quad=$ Dibelajarkan secara konvensional

$\mathrm{O}_{1} \quad=$ Post-test pada kelompok eskperimen

$\mathrm{O}_{2} \quad=$ Post-test pada kelompok kontrol

Pada rancangan ini, terdapat dua kelompok subjek, satu mendapatkan perlakuan (kelompok eksperimen) dan satu kelompok sebagai kontrol. Untuk kelompok eksperimen diberikan pembelajaran dengan menerapkan model pembelajaran Group Investigation berbasis budaya penyelidikan, sedangkan untuk kelompok kontrol pembelajaran secara konvensional. Selanjutnya, dilakukan post-test untuk mendapatkan data kompetensi pengetahuan IPA siswa dari kelompok eksperimen dan kelompok kontrol.

Populasi dalam penelitian ini adalah seluruh kelas IV SD Negeri Gugus Kapten Kompyang Sujana yang terdiri dari 15 kelas yang berjumlah 562 siswa.

Teknik pengambilan sampel pada penelitian ini adalah Random Sampling sehingga setiap kelas mendapatkan peluang yang sama untuk menjadi sampel penelitian.

Untuk menentukan sampel, cara yang digunakan adalah dengan cara pengundian. Cara undian dilakukan dengan menuliskan semua kelas IV di seluruh SD populasi pada masing-masing kertas yang jumlahnya 15 kelas, kemudian kertas digulung. Masukan gulungan kertas ke dalam kotak atau botol dan lakukan pengundian untuk mendapatkan dua kelas. Tahap pengundian pertama dilakukan untuk memilih dua kelas yang akan dijadikan sampel penelitian.

Untuk mengetahui sampel benar-benar setara dari segi akademik, maka dilakukan uji-t kesetaraan dengan syarat sebelum dilakukan uji-t, data nilai ulangan harian IPA siswa harus memenuhi uji prasyarat yang meliputi uji normalitas dan homogenitas variansi. Setelah 
sampel setara, pengundian kedua dilakukan untuk memilih kelas yang akan dijadikan sebagai kelas eksperimen dan kelas kontrol.

Data yang dikumpulkan dalam penelitian ini adalah kompetensi pengetahuan IPA dengan menggunakan metode atau teknik tes. Tes yang digunakan untuk mengumpulkan data kompetensi pengetahuan IPA adalah butir-butir tes jenis objektif bentuk pilihan ganda biasa (multiple choice). Dalam penelitian ini menggunakan tes pilihan ganda biasa yang sudah tervalidasi.

Metode dan analisis data yang digunakan dalam penelitian ini yaitu analisi statistic inferensial.Karena untuk mencari perbedaan, maka analisis inferensial yang digunakan dalam penelitian ini adalan uji-t ( $t$-test). Untuk dapat menggunakan teknik analisis tersebut dibutuhkan data yang berdistibusi normal dan homogen. Maka dari itu, perlu dilakukan uji normalitas data dan uji homogenitas untuk memenuhi prasyarat yang dibutuhkan untuk menggunakan teknik analisis $U j \mathrm{ji}-\mathrm{t}(\mathrm{t}$-test).

\section{HASIL DAN PEMBAHASAN}

Deskripsi data hasil penelitian ini memaparkan mengenai perolehan hasil post-test pada kelompok eksperimen dan kelompok kontrol di SDN Gugus Kapten Kompyang Sujana. Data yang diperoleh dalam penelitian ini dikelompokan menjadi dua yaitu data kompetensi pengetahuan IPA kelompok eksperimen di SD Negeri 9 Padangsambian dan data kompetensi pengetahuan IPA kelompok kontrol di SD Negeri 2 Padangsambian.

Dari data tes kompetensi pengetahuan IPA dengan 30 butir tes soal yang diberikan setelah 6 kali perlakuan, tes diberikan pada tanggal $17 \& 18$ Mei 2019. Banyaknya siswa pada kelompok eksperimen adalah 40 dan kelompok kontrol 39 siswa. Data nilai rata-rata

\begin{tabular}{ccccc}
\hline $\begin{array}{c}\text { Model } \\
\text { Pembelajaran }\end{array}$ & $\begin{array}{c}\text { Jumlah siswa } \\
\text { tiap kelompok }\end{array}$ & Nilai Rata-rata & Varians & Standar Deviasi \\
\hline $\begin{array}{c}\text { Kelompok } \\
\begin{array}{c}\text { Eksperimen } \\
\text { Kelompok } \\
\text { Kontrol }\end{array}\end{array}$ & 40 & 82,80 & 54,73 & 7.40 \\
\hline
\end{tabular}

(M), Varians (S), dan Standar Deviasi (SD) disajikan pada Tabel 1.

\section{Tabel 1. Tabel Nilai Rata-Rata,Varians, dan Standar Deviasi Kompetensi Pengetahuan IPA Kelas IV di SDN Gugus Kapten Kompyang Sujana}

Berdasarkan tabel 1, Nilai rata-rata kompetensi pengetahuan IPA kelompok eksperimen yang dibelajarkan dengan model pembelajaran Group Investigation berbasis budaya penyelidikan adalah $\bar{X}=82,80$ dengan varians sebesar $S^{2}=54,73$ dan standar deviasi $\mathrm{SD}=7,40$. Sedangkan nilai rata-rata kelompok kontrol yang dibelajaran secara konvensional adalah $\bar{X}=73,28$ dengan varians $S^{2}=57,10$ dan standar deviasi $\mathrm{SD}=7,56$.

Uji Normalitas dimaksudkan untuk mengetahui apakah sebaran data kompetensi pengetahuan IPA masing-masing kelompok berdistribusi normal atau tidak sehingga dapat menentukan teknik analisis data. Uji normalitas data dilakukan dengan menggunakan analisis Chi-kuadrat dengan ketentuan harga $X_{\text {hit }}^{2}$ yang diperoleh dibandingkan dengan harga $X_{\text {tabel }}^{2}$ dengan derajat kebebasan $(\mathrm{dk})=\mathrm{k}-1=6-1=5$, maka diperoleh $X_{t a b e l}^{2}=$ 
11,07. Uji normalitas dilakukan terhadap kompetensi pengetahuan IPA baik kelompok

\begin{tabular}{|c|c|c|c|c|}
\hline No. & $\begin{array}{c}\text { Kelompok } \\
\text { Data } \\
\text { Kompetensi } \\
\text { Pengetahuan } \\
\text { IPA }\end{array}$ & $X_{\text {hit }}^{2}$ & $\begin{array}{c}\text { Nilai Kritis dengan Taraf Signifikan } \\
5 \%\end{array}$ & Status \\
\hline 1. & Eksperimen & 10,78 & 11,07 & Normal \\
\hline 2. & Kontrol & 2,74 & 11,07 & Normal \\
\hline
\end{tabular}

eksperimen maupun kelompok kontrol disajikan pada Tabel 2.

\section{Tabel 2. Tabel Rekapitulasi Hasil Uji Normalitas Sebaran Data Kelompok Eksperimen dan Kelompok Kontrol.}

Adapun kriteria pengujian jika $X_{\text {hit }}^{2}<X_{t a b e l}^{2}$ maka data berdistribusi normal, sedangkan jika $X_{\text {hit }}^{2}>X_{\text {tabel }}^{2}$ maka data tidak berdistribusi normal.

Berdasarkan hasil uji normalitas kelompok eksperimen pada tabel diatas, Harga $X_{\text {hit }}^{2}$ yang diperoleh dari kelompok eksperimen yaitu 10,78. Harga tersebut kemudian dibandingkan dengan harga $X_{\text {tabel }}^{2}$ dengan taraf signifikansi $5 \%$ dk $5\left(X_{\text {tabel }}^{2}=11,07\right)$. Hal ini menujukkan $X_{\text {hit }}^{2}<X_{\text {tabel }}^{2}(10,78<11,07)$ yang berarti sebaran data kompetensi pengetahuan IPA kelompok eksperimen berdistribusi normal. Dan berdasarkan hasil uji normalitas kelompok kontrol pada tabel diatas, Harga $X_{\text {hit }}^{2}$ yang diperoleh dari kelompok kontrol yaitu 2,74. Harga tersebut kemudian dibandingkan dengan harga $X_{t a b e l}^{2}$ dengan taraf signifikansi $5 \%$ dk $5\left(X_{\text {tabel }}^{2}=11,07\right)$. Hal ini menujukkan $X_{\text {hit }}^{2}<X_{\text {tabel }}^{2}(2,74<11,07)$ yang berarti sebaran data kompetensi pengetahuan IPA kelompok kontrol juga berdistribusi normal.

Pengujian homogenitas varians bertujuan agar sampel yang diambil benar - benar representatif. Uji homogenitas varians dapat dilakukan apabila kelompok data tersebut dalam distribusi normal. Uji homogenitas varians menggunakan uji Fisher $(F)$. Dengan kriteria apabila $F_{\text {hitung }}<F_{\text {tabel }}$, maka sampel homogen. Pengujian dilakukan pada taraf signifikasi $5 \%$ dengan derajat kebebasan $\left(\mathrm{dk}_{1}\right)$ untuk pembilang $\mathrm{n}_{1}-1$ dan derajat kebebasan $\left(\mathrm{dk}_{2}\right)$ untuk penyebut $\mathrm{n}_{2}-1$. Berdasarkan analisis uji homogenitas varians, pada tabel 3 . disajikan ringkasan hasil uji homogenitas untuk kelompok eksperimen dan kelompok kontrol dengan menggunakan rumus uji Fisher (F).

Tabel 3. Tabel Uji Homogenitas Varians antar Kelompok Eksperimen dan Kelompok Kontrol 
Dari hasil perhitungan diperoleh $\mathrm{F}_{\text {hitung }}=1,04$, harga ini kemudian dibandingkan dengan harga $F_{\text {tabel }}$ dengan derajat kebebasan pembilang $=39-1=38$ dan derajat kebebasan penyebut $=40-1=39$ dengan taraf signifikasi $5 \%$, sehingga diperoleh $F_{\text {tabel }}=1,69$. Karena harga $F_{\text {hitung }}<F_{\text {tabel }}(1,04<1,69)$. Ini berarti varians data kompetensi pengetahuan IPA antara kelompok eksperimen dan kelompok kontrol adalah homogen.

Setelah melalui tahapan uji prasyarat yang meliputi uji normalitas sebaran data dan uji homogenitas varians, data kompetensi pengetahuan IPA kelompok eksperimen maupun kelompok kontrol tersebut dilakukan uji hipotesis untuk menguji hipotesis penelitian dengan kriteria pengujian adalah $\mathrm{H}_{0}$ ditolak jika nilai $\mathrm{t}_{\text {hitung }}>\mathrm{t}_{\text {tabel }}$ pada taraf signifikasi $5 \%$ dengan $\mathrm{dk}$ $=\mathrm{n}_{1}+\mathrm{n}_{2^{-}}$

\begin{tabular}{|c|c|c|c|c|c|c|c|c|}
\hline No. & Sampel & $\begin{array}{l}\text { Rata } \\
\text {-rata }\end{array}$ & Varians & Dk & $\mathrm{N}$ & $\mathrm{t}_{\text {hitung }}$ & $t_{\text {tabel }}$ & $\begin{array}{c}\text { Kesimpula } \\
\mathrm{n}\end{array}$ \\
\hline & Kelas & & & & & & & \\
\hline 1. & Eksperimen & 82,80 & 54,73 & 77 & 40 & 5,694 & 2,000 & $\mathrm{H}_{0}$ ditolak \\
\hline 2. & Kelas Kontrol & 73,28 & 57,10 & & 39 & & & \\
\hline
\end{tabular}

Pengujian hipotesis dapat dilakukan dengan uji-t, karena data yang diperoleh telah memenuhi semua prasyarat yaitu uji normalitas sebaran data dan uji homogenitas varians.

Rekapitulasi hasil analisis uji-t kelompok sampel penelitian ini disajikan pada tabel 4.

\section{Tabel 4. Hasil Analisis Uji-t Data Post-test Kelompok Eksperimen dan Kelompok Kontrol.}

Berdasarkan hasil perhitungan uji-t diperoleh $t_{\text {hitung }}=5,694$ dan untuk $t_{\text {tabel }} 2,000$ dan untuk taraf signifikasi $5 \%$ dengan $\mathrm{dk}=77$ diperoleh $\mathrm{t}_{\text {tabel }}=2,00$. Dengan demikian nilai $\mathrm{t}_{\text {hitung }}>$ $t_{\text {tabel }}$ yakni 5,694 > 2,000 sehingga Ho ditolak. Hal ini menunjukkan bahwa terdapat perbedaan yang signifikan kompetensi pengetahuan IPA pada siswa yang dibelajarkan menggunakan model pembelajaran Group Investigation berbasis budaya penyelidikan

\begin{tabular}{cccc}
$\begin{array}{l}\text { Kelompok } \\
\text { Penelitian }\end{array}$ & $\mathrm{F}_{\text {hitung }}$ & $\begin{array}{c}\text { Nilai } \mathrm{F}_{\text {tabel }} \text { dengan } \\
\text { taraf signifikan 5\% }\end{array}$ & Status \\
\hline $\begin{array}{c}\text { Kompetensi } \\
\begin{array}{c}\text { Pengetahuan IPA } \\
\text { kelompok }\end{array}\end{array}$ & 1,04 & & \\
$\begin{array}{c}\text { eksperimen dan } \\
\text { kontrol }\end{array}$ & & 1,69 & Homogen \\
\hline
\end{tabular}

dengan kelompok siswa yang dibelajarkan menggunakan pembelajaran konvensional. 
Penelitian ini dilaksanakan pada kelas IV SDN Gugus Kapten Kompyang Sujana. Terdapat dua kelas sebagai sampel penelitian, yaitu kelas IV ${ }^{C}$ SD Negeri 9 Padangsambian yang dibelajarkan dengan model pembelajaran Group Investigation berbasis budaya penyelidikan sebagai kelompok eksperimen, kelas IV ${ }^{A}$ SD Negeri 2 Padangsambian yang dibelajarkan secara konvensional sebagai kelompok kontrol.

Berdasarkan hasil analisis data, diperoleh nilai rata-rata kelompok eksperimen $\bar{X}=$ 82,80 dan kelompok kontrol $\bar{X}=73,28$. Ini menunjukkan bahwa nilai rata-rata kelompok eksperimen $\bar{X}=82,80>\bar{X}=73,28$ kelompok kontrol. Lebih lanjut, melalui uji hipotesis diperoleh $t_{\text {hitung }}=5,694$ sedangkan dengan taraf signifikansi $5 \%$ dan $\mathrm{dk}=77$ diperoleh harga $t_{\text {tabel }}=2,000$. Dengan demikian, $t_{\text {hitung }}=5,694>t_{\text {tabel }}=2,000$, sehingga hipotesis nol $\left(H_{0}\right)$ ditolak. Ini berarti terdapat pengaruh model pembelajaran Group Investigation berbasis budaya penyelidikan terhadap kompetensi pengetahuan IPA kelas IV SDN Gugus Kapten Kompyang Sujana. Hal ini disebabkan karena model pembelajaran Group Investigation berbasis budaya penyelidikan merupakan model pembelajaran yang lebih menekankan pada peran siswa untuk mencari sendiri pemecahan masalahnya melalui pembelajaran berbasis budaya penyelidikan.

Penerapan pembelajaran Group Investigation melibatkan seluruh komponen yang dimiliki oleh siswa untuk dapat menemukan suatu proses pembelajaran dalam pencapaian tujuan. Keterlibatan tersebut dapat berbentuk pengekspresian diri serta penggunaan bahasa yang baik dan benar. Model pembelajaran Group Investigation dapat menumbuhkan sikap yang antusias terhadap materi yang disajikan sehingga menimbulkan kesan yang menyenangkan bagi siswa karena siswa tersebut dapat dioptimalkan kegiatannya bersama kelompok yang menumbuhkan rasa percaya diri dan semangat antusiasme belajar pada diri siswa.

Model pembelajaran Group Investigation memiliki dampak positif salah satu diataranya siswa dapat belajar berkomunikasi baik dengan teman sendiri maupun guru. Dalam proses pembelajarannya guru berperan sebagai fasilitator dikarenakan siswalah yang aktif didalam proses pembelajaran. Guru juga dapat memberikan batasan-batasan atau aturan-aturan tertentu dalam menyajikan pembelajaran yang menggunakan model ini, sehingga memiliki kesan guru lebih menonjolkan diri dengan rasa keakraban terhadap siswa. Selain itu, dalam proses penerapannya secara tidak langsung telah menumbuhkan hubungan-hubungun tertentu di antara siswa. Siswa dapat berinteraksi serta menghargai antar temannya. Siswa tidak merasa ada perbedaan di antara teman kelompoknya. Terlebih dapat menghargai sesama teman yang memiliki kepercayaan yang berbeda.

Hal ini sesuai pendapat Shoimin, (2014:80) "Model pembelajaran Group Investigation adalah suatu model pembelajaran yang lebih menekankan pada pilihan dan kontrol siswa daripada menetapkan teknik-teknik pengajaran di ruang kelas". Dalam penerapannya model pembelajaran Group Investigation ini dipadukan dengan pembelajaran berbasis budaya penyelidikan. National Science Education Standards (dalam National Science Teacher's Association 2013:46) menyebutkan bahwa:

Penyelidikan ilmiah mengacu pada berbagai macam cara yang dipakai ilmuwan, untuk mempelajari alam dan mengungkapkan penjelasan berdasarkan bukti yang mereka peroleh dari proses itu. Penyelidikan juga mengacu pada aktivitas yang dilakukan siswa untuk mengembangkan pengetahuan dan pemahaman mengaai gagasan-gagasan ilmiah,serta pemahaman mengenai bagaimana ilmuwan memelajari alam. 
Tugas tersebut dapat berupa investigasi, atau penelitian sederhana tentang suatu masalah yang berkaitan dengan materi (KD) tertentu mulai dari perencanaan, pengumpulan data atau informasi, pengolahan data, penyajian data atau laporan. Budaya Penyelidikan dimaksudkan untuk mengetahui pemahaman, kemampuan mengaplikasikan, kemampuan penyidikan, dan kemampuan menginformasikan diri secara jelas.

Perbedaan perlakuan yang diberikan pada kelompok eksperimen diberikan perlakuan dengan model pembelajaran Group Investigation berbasis budaya penyelidikan dan pada kelompok kontrol tidak diberikan perlakuan dengan model pembelajaran Group Investigation berbasis budaya penyelidikan sehingga kompetensi pengetahuan IPA kurang optimal dibandingkan dengan kelompok eksperimen.

Penelitian ini relevan dengan penelitian yang dilakukan oleh Dewi (2017) yang menyatakan bahwa model pembelajaran Group Investigation berbasis proyek berpengaruh terhadap hasil belajar IPA kelas IV SD Gugus 1 Abiansemal. Demikian juga diperkuat oleh penelitian yang dilakukan Astiti (2017) yang menyatakan bahwa model pembelajaran Children Learning In Science berbasis budaya penyelidikan berpengaruh terhadap kompetensi pengetahuan IPA kelas V SD Gugus Srikandi Denpasar Timur

\section{SIMPULAN}

Berdasarkan hasil analisis dengan uji-t, diperoleh $t_{\text {hitung }}=5,694$. Pada taraf signifikasi $5 \%$ dan derajat kebebasan $(\mathrm{dk})=40+39-2=77$ maka diperoleh harga $t_{\text {tabel }}=2,000$. Berdasarkan hasil tersebut, diperoleh $t_{\text {hitung }}=5,694>t_{\text {tabel }}=2,000$. Dengan demikian Ho yang menyatakan bahwa tidak terdapat perbedaan yang signifikan kompetensi pengetahuan IPA antara kelompok eksperimen yang dibelajarkan menggunakan model pembelajaran Group Investigation berbasis budaya penyelidikan dan kelompok kontrol yang dibelajarkan menggunakan pembelajaran konvensional pada kelas IV SDN Gugus Kapten Kompyang Sujana ditolak. Selain itu, berdasarkan hasil penelitian nilai rata - rata kompetensi pengetahuan IPA kelompok eksperimen lebih dari rata-rata kompetensi pengetahuan IPA kelompok kontrol $\left(\bar{X}_{1}=82,80>\bar{X}_{2}=73,28\right)$, jadi dapat disimpulkan bahwa terdapat pengaruh model pembelajaran Group Investigation berbasis budaya penyelidikan terhadap kompetensi pengetahuan IPA kelas IV SDN Gugus Kapten Kompyang Sujana. Berdasarkan hasil penelitian ini, maka dapat diajukan beberapa saran 1) guru hendaknya menjadikan hasil penelitian ini sebagai bahan pertimbangan dalam menyusun perencanaan pembelajaran karena hasil penelitian ini menunjukan bahwa terdapat pengaruh model pembelajaran Group Investigation berbasis budaya penyelidikan terhadap kompetensi pengetahuan IPA, 2) kepala sekolah, sebaiknya menyediakan fasilitas pembelajaran yang lengkap sehingga siswa dapat menfaatkan fasilitas tersebut dan guru dapat membelajarkan siswa dengan model-model pembelajaran inovatif seperti model pembelajaran Group Investigation berbasis budaya penyelidikan untuk mengoptimalkan kompetensi pengetahuan siswa.

\section{DAFTAR PUSTAKA}

Agung, A. A. Gede. 2014. Pengantar Evaluasi Pendidikan. Singaraja : FIP Undiksha

Agung, A. A. Gede. 2014. Metodologi Penelitian Pendidikan. Malang: Aditya Media Publishing. 
Arikunto, Suharsimi. 2013. Dasar-Dasar Evaluasi Pendidikan Ed. 2. Jakarta: PT Bumi Aksara.

Arikunto, Suharsimi. 2018. Dasar-Dasar Evaluasi Pendidikan. Jakarta : PT Bumi Aksara.

Astiti, Ni Putu Mia. 2017. Pengaruh Model Pembelajaran Children Learning In Science Berbasis Budaya Penyelidikan Terhadap Kompetensi Pengetahuan IPA Siswa Kelas V SD Gugus Srikandi Denpasar Timur Tahun Ajaran 2016/2017. Jurusan Pendidikan Guru Sekolah Dasar FIP Undiksha, Volume 1, Nomor 2. Tersedia pada http:/e-journal.undiksha.ac.id (diakses tanggal 24 Januari 2019).

Dewi, Pande Putu Yustika. 2017. Pengaruh Model Pembelajaran Group Investigation Berbasis Proyek Terhadap Hasil Belajar IPA Siswa Kelas IV SD Gugus 1 Abiansemal Tahun Ajaran 2016/2017. Jurusan Pendidikan Guru Sekolah Dasar FIP Undiksha, Volume 2, Nomor 4. Tersedia pada http:/ejournal.undiksha.ac.id (diakses tanggal 24 Januari 2019).

Kosasih. 2014. Strategi Belajar Dan Pembelajaran. Bandung : Yrama Widya.

Kurniasih, Imas dan Sani, Berlin. 2014. Sukses Mengimplementasikan Kurikulum2013 Kata Pena.

Kurniasih, Imas dan Sani, Berlin. 2016. Ragam Pengembangan Model Pembelajaran: Kata Pena.

Mulyasa, E. 2015. Pengembangan dan Implementasi Kurikulum 2013. Bandung: PT Remaja Rosdakarya

Nalasari, Kd Anggi. 2016. Penerapan Inkuiri Terbimbing Dalam Pendekatan Saintifik Berbasis Budaya Penyelidikan Untuk Meningkat Keaktifan Dan Pengetahuan IPA. Jurusan Pendidikan Guru Sekolah Dasar FIP Undiksha, Volume 4, Nomor 1.Tersedia pada http:/e- journal.undiksha.ac.id (diakses tanggal 24 Januari 2019).

National Science Teacher's Association. 2013. Buku Pedoman Guru Biologi. $\quad$ Edisi ke-4. Diterjemahkan oleh Sarwiji, Bambang. Jakarta : PT Indeks.

Salimah. 2011. Dampak Penerapan Bermain Dengan Media Gambar Seri Dalam Mengembangkan Ketrampilan Berbicara Dan Penguasaan Kosa Kata Anak Usia Dini. Edisi Khusus Nomor 1. Tersedia pada Jurnal.upi.edu (diakses tanggal 24 Januari 2019)

Samatowa, Usman. 2016. Pembelajaran IPA di Sekolah Dasar. Jakarta : PT Indeks.

Sani, Ridwan Abdullah. 2015. Pembelajaran Saintifik untuk Implementasi Kurikulum 2013. Jakarta: Bumi Aksara.

Setyosari, Punaji. 2015. Metode Penelitian Pendidikan dan Pengembangan. Jakarta : Bumi Aksara.

Shoimin, Aris. 2014. 68 Model Pembelajaran Inovatif dalam Kurikulum 2013. Yogyakarta : Ar-Ruzz Media.

Sugiyono. 2011. Metode Penelitian Kombinasi (Mixed Mothods). Bandung:Alfabeta.

Sugiyono. 2017. Statistika Untuk Penelitian. Bandung : Alfabeta

Sugiyono. 2018. Metode Penelitian Pendidikan. Bandung : Alfabeta

Susanto, Ahmad. 2013. Teori Belajar Dan Pembelajaran Di Sekolah Dasar. Jakarta : Kencana.

Undang-undang Republik Indonesia No. 20 Tahun 2003 tentang Sistem Pendidikan Nasional. 2003. Jakarta: Sekretaris Negara Republik Indonesia.

Yusuf, Muri. 2017. Asesmen dan Evaluasi Pendidikan. Jakarta: Prenandamedia Group. 